\title{
EVALUASI MUTU PELAYANAN GIZI DITINJAU DARI PROSES ASUHAN GIZI TERSTANDART (PAGT) \\ DI RAWAT INAP RSUD GAMBIRAN KOTA KEDIRI \\ Reny Nugraheni
}

\section{LATAR BELAKANG}

$>$ Empat faktor utama yang mempengaruhi derajat kesehatan masyarakat salah satunya adalah pelayanan kesehatan (H.L. Blum)

- Pelayanan gizi di rumah sakit berperan dalam mempercepat penyembuhan pasien (Sukadi dan Sri Wahyuningsih, 2015)

pasien yang dirawat dirumah sakit membutuhkan asupan makanan dan gizi sesuai dengan jenis penyakit yang dideritanya (Saleh, 2017)

RSUD

Gambiran

adalah RS

Tipe B dan

tingkat

kunjungan

Ranap

tertinggi

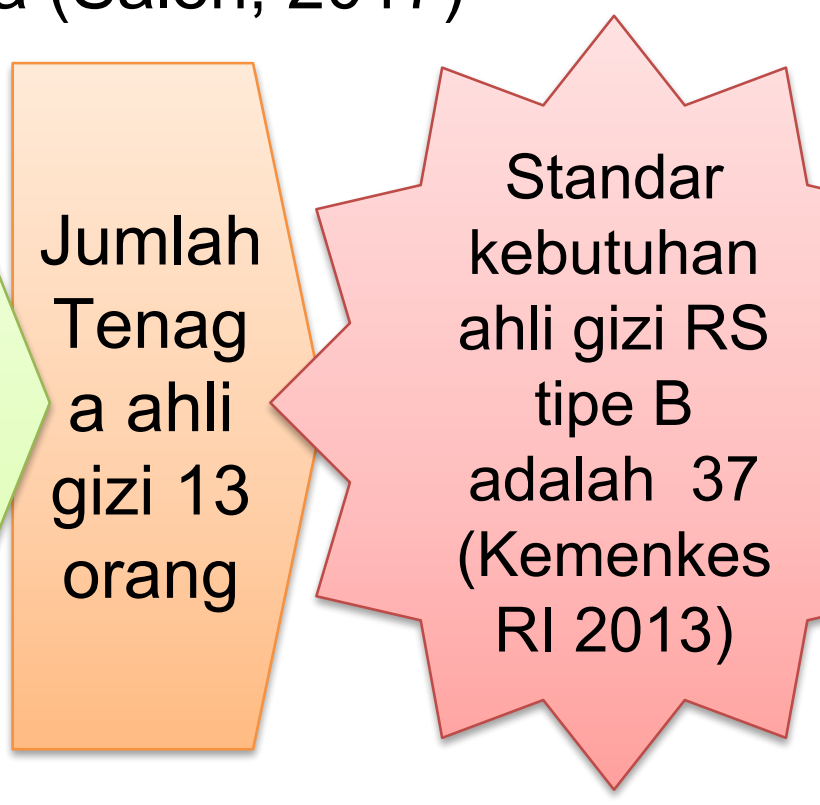

Berdasarkan uraian fakta dan teori di atas, maka perlu dilakukan penelitian tentang evaluasi mutu pelayanan ditinjau dari PAGT di Rawat Inap RSUD Gambiran Kediri

\section{TUJUAN}

Tujuan penelitian ini adalah Menganalisis Mutu Pelayanan Gizi ditinjau dari Proses Asuhan Gizi Terstandart (PAGT) di Rawat Inap RSUD Gambiran Kota Kediri

\section{METODE}

Jenis penelitian ini adalah penelitian survel deskriptif dengan rancangan penelitian evaluation study.

- Populasi dalam penelitian ini adalah seluruh data rekam medik pasien rawat inap pada Bulan Januari-Agustus Tahun 2017 sebanyak 4200 pasien dan besar sampel adalah 94 pasien dan diambil menggunakan simple random sampling.

HASIL

Tabel 1. Mutu Pelayanan Ditinjau Dari Proses Asuhan Gizi Terstandart (PAGT)

\begin{tabular}{|c|c|c|}
\hline No. & Standar Penilaian & $\begin{array}{c}\text { Capaian } \\
\text { Kesesuaian } \\
\text { Standar } \\
\text { Penilaian } \\
(\%)\end{array}$ \\
\hline 1. & $\begin{array}{l}\text { Assesmen Gizi } \text { Diberikan } \\
\text { Tepat Waktu } \\
\text { 2x24jam) }\end{array}$ & $99 \%$ \\
\hline 2. & $\begin{array}{l}\text { Asuhan Gizi Tercatat Dalam } \\
\text { Lembar CPPT }\end{array}$ & $97 \%$ \\
\hline 3. & $\begin{array}{l}\text { Asuhan Gizi Direvisi Sesuai } \\
\text { Respon Pasien }\end{array}$ & $95 \%$ \\
\hline 4. & $\begin{array}{l}\text { Monitoring Asuhan Gizi } \\
\text { Dilakukan }\end{array}$ & $89 \%$ \\
\hline 5. & $\begin{array}{l}\text { Asuhan Gizi Diberikan Oleh } \\
\text { Dietisien }\end{array}$ & $100 \%$ \\
\hline 6. & $\begin{array}{l}\text { Kesesuaian Intervensi } \\
\text { Sesuai Kondisi Pasien }\end{array}$ & $100 \%$ \\
\hline & Rata-Rata & $97 \%$ \\
\hline
\end{tabular}

Sumber: Data Sekunder, 2017
1. Distribusi Penilaian Assesmen Gizi Diberikan Tepat Waktu (Maximal $2 \times 24 j a m)$ : tenaga gizi atau dietisien di rawat inap RSUD Gambiran Kota Kediri idak berada 24 jam penuh di ruangan kerja

2. Distribusi Penilaian Asuhan Giz Tercatat Dalam Lembar CPPT pengisian CPPT yang masih manual selain itu lembar CPPT tersebut digunakan bergantian dari tenaga kesehatan satu dengan yang lainnya

3. Distribusi Penilaian Asuhan Gizi Direvisi Sesuai Respon Pasien : sikap kurang teliti dari ahli gizi ruangan

4. Distribusi Penilaian Monitoring Asuhan Gizi Dilakukan : kurangnya SDM tenaga gizi yang bekerja $d i$ instalasi gizi RSUD Gambiran Kota Kediri

5. Distribusi Penilaian Asuhan Giz Diberikan Oleh Dietisien : standar penilaian asuhan gizi yang diberikan kepada pasien dilakukan oleh dietisien menunjukan presentase sebesar 100\% sesuai standar

6. Distribusi Penilaian Kesesuaian Intervensi Sesuai Kondisi Pasien. Semua ahli gizi di ruangan sudah menuliskan intervensi gizi yang akan diberikan kepada pasien secara lengkap dan sesuai ketentuan.
Diagram Mutu Pelayanan Gizi Ditinjau Dari Proses Asuhan Gizi Terstandart (PAGT) di Rawat Inap RSUD Gambiran Kota Kediri

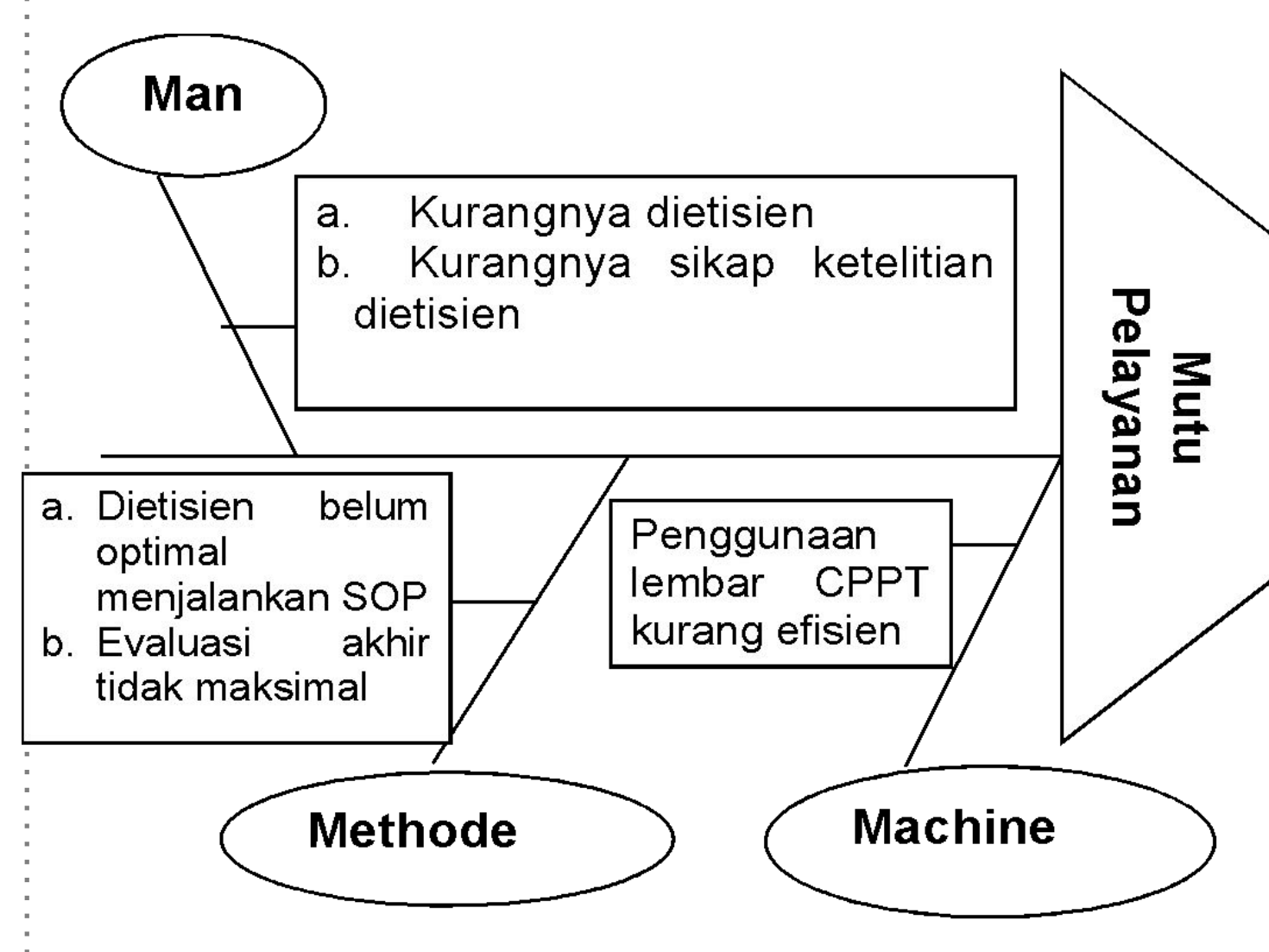

\section{KESIMPULAN}

Penilaian mutu pelayanan gizi ditinjau dari PAGT di rawat inap RSUD Gambiran Kota Kediri didapatkan presentase rata-rata capaian adalah $97 \%$ yang artinya adalah tidak terpenuhi sehingga masih belum sesuai standar

REFERENSI
1 Bustami. 2011. Penjaminan Mutu Pelayanan Kesehatan dan Akseptabilitas. Jakarta: Erlangga.

Herawati,dk. 2015. Analisis Pelayanan Gizi Rumah Sakit dengan Pendekatan Health Technology Assessement (HTA). JSK, Volume 1
Nomor. 2 Tahun 2015
3 Lameshow, S, dkk. 1990. Adequacy of Sample Size in Health Studies

by World Health Organization

4 Moss, F. 1994. Spreading The Word; Information For Quality. Quality in Health Care; 3 , Supplement; $46-50$

5 Muninjaya. 2014. Manajemen Mutu Kesehatan. Jakarta: EGC 6 Saleh, K. 2017. Buku Pedoman Pelatihan di RSUP dr. Wahidin

\section{7rd 아 Public Health UUGM Symposium}

